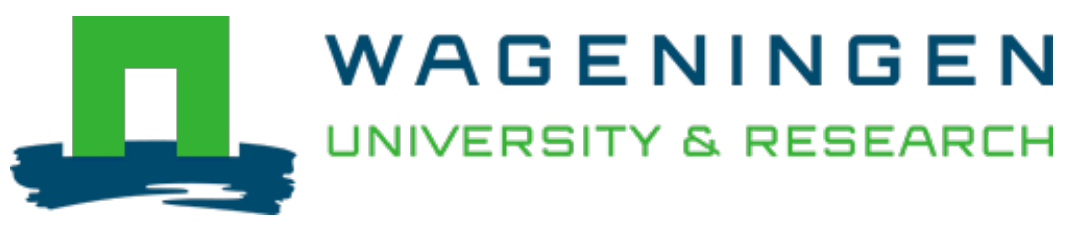

\title{
Perspectives on the functional assessment of multi-stressed stream ecosystems
}

Freshwater Science

Verdonschot, Piet F.M.; Lee, Gea H.

https://doi.org/10.1086/711707

This publication is made publicly available in the institutional repository of Wageningen University and Research, under the terms of article $25 \mathrm{fa}$ of the Dutch Copyright Act, also known as the Amendment Taverne. This has been done with explicit consent by the author.

Article $25 \mathrm{fa}$ states that the author of a short scientific work funded either wholly or partially by Dutch public funds is entitled to make that work publicly available for no consideration following a reasonable period of time after the work was first published, provided that clear reference is made to the source of the first publication of the work.

This publication is distributed under The Association of Universities in the Netherlands (VSNU) 'Article $25 \mathrm{fa}$ implementation' project. In this project research outputs of researchers employed by Dutch Universities that comply with the legal requirements of Article $25 \mathrm{fa}$ of the Dutch Copyright Act are distributed online and free of cost or other barriers in institutional repositories. Research outputs are distributed six months after their first online publication in the original published version and with proper attribution to the source of the original publication.

You are permitted to download and use the publication for personal purposes. All rights remain with the author(s) and / or copyright owner(s) of this work. Any use of the publication or parts of it other than authorised under article $25 \mathrm{fa}$ of the Dutch Copyright act is prohibited. Wageningen University \& Research and the author(s) of this publication shall not be held responsible or liable for any damages resulting from your (re)use of this publication.

For questions regarding the public availability of this publication please contact openscience.library@,wur.nl 


\title{
Perspectives on the functional assessment of multi-stressed stream ecosystems
}

\author{
Piet F. M. Verdonschot ${ }^{1,2,3}$ and Gea H. van der Lee ${ }^{1,2,4}$ \\ ${ }^{1}$ Institute for Biodiversity and Ecosystem Dynamics, University of Amsterdam, P.O. Box 94240, 1090 GE Amsterdam, The Netherlands \\ ${ }^{2}$ Wageningen Environmental Research, Wageningen University and Research, P.O. Box 47, 6700 AA Wageningen, The Netherlands
}

\begin{abstract}
Past research has examined how anthropogenic stressors affect both structural and functional attributes of stream ecosystems. Nevertheless, biomonitoring programs rely mostly on structural metrics for surface-water quality and status assessments, and few studies have examined the extent to which functional metrics can strengthen these structure-based assessments. We reviewed studies that combined the response of stream-ecosystem structural and functional measures to single and multiple stressors. These studies illustrate that structural and functional measures can respond in similar, complementary, or even contradictory magnitude and direction to different stressors. Because of this complexity, we suggest that a combination of structural and functional measures may provide added information on surface-water quality and status, especially when ecosystems are affected by multiple stressors. Better knowledge about trophic and non-trophic roles of dominant taxa and the effects of changes in species diversity on stream ecosystem processes could improve understanding of the relationships among structural and functional measures. Based on our review, we suggest that future research should be designed to: 1) increase understanding of the roles of individual species and communities in the functioning of stream ecosystems, and 2) quantify the responses of individual species and communities to individual stressors and combinations of multiple stressors. We propose that increasing the knowledge base about the suites of traits that occur in different species, how these traits coevolved under local environmental abiotic and biotic conditions, and how they interact is needed to understand how multiple stressors affect ecosystem structure and function. This trait-based knowledge is essential to understanding the relationship between structure and function in multi-stressed stream ecosystems and could help managers to make stronger inferences about the combined effects of multiple stressors on water quality and status. Key words: process, structure, primary production, respiration, decomposition, species composition, invertebrates, microbes, algae, fungi, disturbance, stressor
\end{abstract}

In 1960, Hynes (1960) used measures of several biological groups and biological-oxygen demand to describe patterns of structural and functional responses to a point discharge of organic waste into a river. Since then, the effects of anthropogenic stressors on both structural and functional attributes of stream ecosystems have been increasingly studied (Dale and Beyeler 2001, Giller et al. 2004, Young et al. 2008, von Schiller et al. 2017). Nevertheless, most water-quality assessment strategies rely on structural metrics like indicator species, species diversity, and species composition (e.g., Rosenberg and Resh 1993, Bailey et al. 2004). For example, the United States Clean Water Act and the European Union Water Framework Directive use biological indicators, mostly consisting of structural metrics based on species composition and ecosystem structure, to assess ecosystem integrity or ecological status, respectively (USEPA 2002, Birk et al. 2012). Communities, especially those including macroinvertebrates, are frequently used for assessment because they can be diverse and because species replacement or losses can occur in response to a variety of anthropogenic stressors (e.g., Clapcott et al. 2012). Although structural metrics are assumed to measure deviation from a desired ecological condition, they provide limited information on how ecosystems function or how those functions are affected by stressors in tandem with structural measures (Dale and Beyeler 2001, Tilman 2001). A large body

E-mail addresses: ${ }^{3}$ piet.verdonschot@wur.nl; ${ }^{4}$ gea.vanderlee@wur.nl

DOI: 10.1086/711707. Received 14 August 2020; Accepted 31 August 2020; Published online 19 October 2020; Associate Editor, Christoph Matthaei. Freshwater Science. 2020. 39(4):605-620. () 2020 by The Society for Freshwater Science. 
of evidence now shows that stressors may affect the structure and function of ecosystems differently, indicating that assessments should not only be based on what organisms are present but should also directly measure ecosystem processes or functions (Boulton 1999, Karr 1999, Loreau 2002, Gücker et al. 2006, Bergfur et al. 2007, Palmer and Febria 2012). A primary goal of many biomonitoring programs is to detect whether anthropogenic stressors affect ecosystem integrity, and using a combination of ecosystem structural and functional measures could help water managers to make stronger inferences about the effects of stressors on ecosystem integrity (Young et al. 2008, Feio et al. 2010).

Some studies have inferred function from a structural perspective using food webs (Hladyz et al. 2011b), functional feeding groups (Cummins and Klug 1979), or other adaptive and functional traits to better understand and explain ecosystem processes (Dolédec et al. 1999, McGill et al. 2006, Bergfur et al. 2007, Poff et al. 2010, Frainer and McKie 2015, Raffard et al. 2017, Truchy et al. 2019). Adaptive and functional traits refer to organismal processes (e.g., the ability to assimilate nutrients) that may influence processes at higher organizational levels. True ecosystem processes are complex and dynamic operations among interacting abiotic and biotic components, such as leaf-litter breakdown (Gessner and Chauvet 2002), ecosystem metabolism (Fellows et al. 2006), primary and secondary production (Wallace et al. 1996, Udy et al. 2006), and nutrient cycling (Niyogi et al. 2004, Bukaveckas 2007, Marcarelli et al. 2011). Measurements of functional metrics that provide insights into these true ecosystem processes are relatively inexpensive, straightforward to carry out, and, in the case of metabolism, amenable to automation (Collier et al. 2013). Several review papers discuss how these ecosystem processes relate to specific stressors (e.g., Webster and Benfield 1986, Young et al. 2008, Tank et al. 2010) but do not explicitly compare the use of functional and structural metrics for water-quality and status assessments. Moreover, streams and rivers commonly experience multiple, co-occurring anthropogenic stressors (Ormerod et al. 2010, Schäfer et al. 2016), which can complicate structural and functional responses. A key question, thus, remains as to what extent including functional measures of stream ecosystems, in addition to more traditional structural measures, can strengthen the ability of water-quality and status assessments to make inferences about the effects of stressors on ecosystem integrity, particularly when assessed ecosystems are affected by multiple stressors.

To shed light on this question, we first review studies that assessed the effects of a single stressor on both structural and functional measures, discuss the similarities and differences between structural and functional responses within and among studies, and pinpoint potential causes for these differences. We then expand our review to studies on the effects of multiple stressors on combined structural and functional measures. Next, we explore ideas about how mechanistic understanding of structure and related processes (i.e., functional roles of species) can improve assessment of stream ecosystems. Finally, we provide perspectives on future directions for assessment of multiple stressors on stream ecosystems. It should be noted that we did not include all papers published on this topic; rather, we included a relevant subset to provide insights and perspectives into what current research can offer toward informing water managers about stressor effects on water-quality and statusassessment measures.

\section{COMPARING STRUCTURAL AND FUNCTIONAL ASSESSMENTS OF SINGLE STRESSORS}

Responses by structural and functional measures to different stressors can be similar, complementary, or even contradictory in magnitude and direction, both within and between studies. Here, we define stressor as an environmental factor that acts as a debilitating agent to create degradation in an ecosystem (Odum et al. 1979). A selection of studies that assessed the effects of stressors on combined structural and functional response measures is listed in Table 1. Below, we highlight several studies to exemplify the different types of structural and functional responses.

\section{Similar responses in magnitude and direction}

There is consensus on several structural and functional indicators that respond in obvious and unidirectional ways to specific stressors, supporting the idea that changes in structural measures are indicative of changes in function. Such generalizations can be made, for example, for the response of structural measures based on algae and macrophytes and functional measures based on primary productivity. Nutrients, light, and sufficiently warm temperatures are required for photosynthesis. An increase in these factors generally favors fast-growing, dominant species of algae (Smucker et al. 2014, Burson et al. 2018) and macrophytes (Barko et al. 1986), which, in turn, stimulate higher primary production (e.g., Phinney and McIntire 1965, Steinman and McIntire 1987, Bott et al. 2006, Dodds 2006, Bernot et al. 2010, Rasmussen et al. 2011). Cyanobacteria thrive under high temperature and nutrient conditions, and they can outcompete green algae that, in turn, outcompete diatoms (Patrick et al. 1969, Vermaat and Hootsmans 1994, Allan et al. 2006). Increased nutrient loads also cause changes in phytoplankton species composition, even if the N:P ratio of the nutrient loads remains constant, by shifting species interactions from competition for nutrients to competition for light (Burson et al. 2018). As nutrients increase, either through eutrophication or organic pollution, the growth and survival prospects of particular species of primary producers causes increases in their biomass. Increased biomass then leads to more nutrient recycling and energy flow, which subsequently causes changes in species composition, dominance, 
Table 1. A selection of studies providing mechanistic (structure-based) drivers of functional responses to anthropogenic stressors.

\begin{tabular}{|c|c|c|c|}
\hline \multirow[b]{2}{*}{ Structural measure } & \multicolumn{3}{|c|}{ Functional measure } \\
\hline & Production & Respiration & Decomposition \\
\hline Bacteria & Corcoll et al. 2015 & $\begin{array}{l}\text { Masseret et al. 1998, Car- } \\
\text { lisle and Clements } 2005\end{array}$ & $\begin{array}{l}\text { Pascoal et al. 2001, Lecerf et al. 2006, } \\
\text { Hladyz et al. 2011a }\end{array}$ \\
\hline Fungi & & & $\begin{array}{l}\text { Suberkropp and Chauvet 1995, Bärlocher and } \\
\text { Corkum 2003, Gulis and Suberkropp 2003, } \\
\text { Ferreira et al. 2006b, Gulis et al. 2006, } \\
\text { Bergfur et al. 2007, Castela et al. 2008, } \\
\text { Lecerf and Chauvet 2008, Bruder et al. } 2016\end{array}$ \\
\hline Algae & $\begin{array}{l}\text { Crossey and La Point 1988, } \\
\text { Masseret et al. 1998, Cardinale and } \\
\text { Palmer 2002, Uehlinger et al. 2003, } \\
\text { Death et al. 2009, Hladyz et al. } \\
\text { 2011a, Corcoll et al. 2015, } \\
\text { Truchy et al. } 2019\end{array}$ & $\begin{array}{l}\text { Crossey and La Point } \\
\text { 1988, Corcoll et al. } \\
2015\end{array}$ & Smeti et al. 2019 \\
\hline Macrophytes & & & Gücker et al. 2006 \\
\hline $\begin{array}{l}\text { Macroinvertebrates } \\
\text { (general) }\end{array}$ & $\begin{array}{l}\text { Clapcott et al. 2010, } \\
\text { Savoy et al. } 2019\end{array}$ & Clapcott et al. 2010 & $\begin{array}{l}\text { Robinson et al. 1998, Jonsson and Malmqvist } \\
\text { 2000, Loreau 2002, Woodcock and Huryn } \\
\text { 2004, Acuña et al. 2005, Gücker et al. 2006, } \\
\text { Hagen et al. 2006, Bergfur et al. 2007, Dang } \\
\text { et al. 2009, Death et al. 2009, Gücker et al. } \\
\text { 2009, McKie et al. 2009, Riipinen et al. 2009, } \\
\text { Clapcott et al. 2010, Hladyz et al. 2011a, } \\
\text { Schäfer et al. 2012b, Collier et al. 2013, Smeti } \\
\text { et al. 2019, Truchy et al. } 2019\end{array}$ \\
\hline Shredders & & & $\begin{array}{l}\text { Dangles and Guerold 2001, Pascoal et al. } \\
\text { 2001, Huryn et al. 2002, Jonsson et al. 2002, } \\
\text { Jonsson and Malmqvist 2003, Dangles et al. } \\
\text { 2004, Woodcock and Huryn 2004, Carlisle } \\
\text { and Clements 2005, Gulis et al. 2006, Lecerf } \\
\text { et al. 2006, McKie et al. 2006, Bergfur et al. } \\
\text { 2007, McKie and Malmqvist 2009, Riipinen } \\
\text { et al. 2009, Frainer et al. 2014 }\end{array}$ \\
\hline Grazers & $\begin{array}{l}\text { Hill et al. 2001, Friberg et al. 2009, } \\
\text { Hladyz et al. 2011a }\end{array}$ & & \\
\hline Filter-feeders & $\begin{array}{l}\text { Cardinale and Palmer 2002, } \\
\text { Friberg et al. } 2009\end{array}$ & & $\begin{array}{l}\text { Cardinale and Palmer 2002, } \\
\text { Cardinale et al. } 2002\end{array}$ \\
\hline
\end{tabular}

abundance, and secondary production of higher trophic levels (Smucker et al. 2014).

Changes in flow can also affect algal and macrophyte community structure and primary productivity. Low flows generally enhance primary production through increased light availability and nutrient concentrations because of decreased dilution and increased substrate stability, as well as because of reduced shear stress on periphyton and enhanced macrophyte establishment (e.g., Acuña et al. 2010, Marcarelli et al. 2010, Val et al. 2016). In the opposite response direction, floods generally result in decreased primary production because substrate stability decreases, causing higher turbidity that may reduce light conditions (e.g., Uehlinger 2000, Morgan et al. 2006, Roberts et al. 2007,
Leggieri et al. 2013, Val et al. 2016). Furthermore, scouring reduces the abundance, biomass, and diversity of macrophytes and algae, especially periphyton (Riis and Biggs 2003, Wellnitz and Rader 2003, Vilches and Giorgi 2010). Toxicants and other forms of chemical pollution may also inhibit primary production if the algal and macrophyte taxa present are sensitive to the particular substance (Peters et al. 2013). For example, acid mining was related to both a decline in species diversity of algal-dominated periphyton (structural measure) and decreased productivity (functional measure) (Smucker et al. 2014).

Other generalizations can be drawn for the responses of structural measures based on macroinvertebrates and functional measures based on organic-matter breakdown. 
Historically, benthic macroinvertebrate species composition has constituted the basis for most biomonitoring programs worldwide because of their indicative value for assessing oxygen depletion resulting from organic pollution (Wiederholm 1980, Rosenberg and Resh 1993). It is well established that lowered dissolved oxygen alters macroinvertebrate assemblage composition through a loss of oxygensensitive species like key shredders (Gelroth and Marzolf 1978, Schlief and Mutz 2009), which tends to slow down organic-matter breakdown rates (Chauvet 1997, Pascoal and Cássio 2004). Similar responses in both magnitude and direction are observed for other stressors that have a large impact on macroinvertebrate assemblages and subsequently influence organic-matter breakdown, such as metal pollution (Carlisle and Clements 2005, Chaffin et al. 2005), pesticides (Schäfer et al. 2007), and salinity (Schäfer et al. 2012b). Likewise, macroinvertebrate communities are also sensitive to low flows and droughts (Dewson et al. 2007), and as conditions become unfavorable for key shredder species, the organic-matter breakdown rates tend to lower uniformly (Gelroth and Marzolf 1978, Schlief and Mutz 2009, MendozaLera et al. 2012, González et al. 2013, Monroy et al. 2016).

\section{Complementary responses}

Various studies have found that structural and functional measures were complementary and should be used in concert to capture a broader range of potential effects and provide insights into the functional consequences of changes in community structure (e.g., Pascoal et al. 2001, Friberg et al. 2009, Collier et al. 2013). For example, Pascoal et al. (2001) found that macroinvertebrates increased in density but decreased in taxon diversity in response to an increase in nutrient concentrations, while leaf breakdown rates increased substantially. Friberg et al. (2009) also found an increase in density and a decrease in diversity of invertebrates, as well as a subsequent increase in organic-matter breakdown rates, in response to higher temperatures. In contrast, some other structural (macrophyte and fish assemblage composition) and functional (algal productivity) measures did not respond to changes in temperature (Friberg et al. 2009). The difference in structural- and functional-measure response sensitivity to reach-scale pressures and local habitat conditions, and their differences in response at multiple spatial scales, may strengthen their complementarity (Collier et al. 2013) in informing stream assessments.

Several studies have argued that functional measures are more sensitive than structural measures to changes in stressors (e.g., Dangles et al. 2004, Gulis et al. 2006, Riipinen et al. 2009). Gulis et al. (2006) showed that in study streams classified by a macroinvertebrate index as having very good ecological conditions, organic-matter breakdown rates responded to low levels of eutrophication. In other studies, leaf-litter breakdown responded more strongly than total abundance, biomass, and species diversity of detritivores to acidification (Dangles et al. 2004, Riipinen et al. 2009). Moreover, it has been argued that functional measures have added value when included in assessments because they vary less among bioregions than structural measures do (e.g., Clapcott et al. 2010).

Other studies have found higher variability in functional vs structural measures (e.g., Crossey and La Point 1988, Bergfur et al. 2007, Death et al. 2009). Crossey and La Point (1988) looked at the effectiveness of community production and respiration measurements as biomonitoring tools for environmental impacts, and their results indicated that inherent variability may limit the use of these communitylevel functional measures in routine environmental monitoring. Similarly, Bergfur et al. (2007) and Death et al. (2009) concluded that macroinvertebrate metrics performed much better than leaf-litter breakdown rates along nutrient enrichment and water abstraction gradients, respectively. In the case of Death et al. (2009), the lack of functional response to water abstraction could only be explained by more thorough investigation of the individual responses of each of their study streams, which did not add to the efficiency of assessment.

Finally, an example by Uehlinger et al. (2003) showed that there may also be differences between the impact and recovery patterns of structural and functional measures. They found that even though metabolism and assemblage composition of periphyton were both changed by a flood event, metabolism recovered relatively quickly, whereas there was a persistent shift in the periphyton structure (Uehlinger et al. 2003). Thus, structural and functional measures may provide complementary information on the assessment of impact and recovery patterns over time.

\section{Variable and non-linear responses}

In some cases, different responses to the same stressor have been reported for structural and functional measures across studies. For example, loss of fungal diversity and lowered organic-matter breakdown rates in nutrientenriched streams reported by Lecerf and Chauvet (2008) contrasted with the results of other nutrient-enrichment experiments showing either a positive effect on both fungi and organic-matter breakdown (Gulis and Suberkropp 2003) or no effect at all (Ferreira et al. 2006a). A systematic quantitative assessment of litter decomposition across a gradient of nutrient enrichment at the continental scale by Woodward et al. (2012) showed that breakdown rates were low at both ends of the nutrient gradient. Processing rates may increase in moderately stressed systems, whereas processing rates may be suppressed under the influence of high stress, leading to a non-linear functional response (Niyogi et al. 2002, Young and Collier 2009, Clapcott et al. 2010, Woodward et al. 2010). Similarly, moderate degrees of eutrophication may result in a more diverse community of producers and consumers (Rosenzweig 1995, Townsend 
et al. 1998, Thompson and Townsend 2005), but a further increase of eutrophication can cause algal blooms. The associated low dissolved oxygen and poor habitat conditions generally decrease species diversity (e.g., Dodds 2006, Niyogi et al. 2007, Dunck et al. 2015). These examples illustrate the importance of assessing a sufficiently long stressor gradient to capture the range of possible structural and functional responses (Woodward et al. 2012, Feld et al. 2016).

Environmental conditions specific to different locations and points in time may also alter assessment results. Conditions related to climate or season, such as temperature oscillations (e.g., Dang et al. 2009), flow velocity (e.g., Ferreira et al. 2006b), and the quantity of organic matter in the stream (e.g., Roberts et al. 2007), may elicit different structural and functional responses, with detection of responses depending on where and when stressor impacts are assessed. For example, temperature can strongly affect toxicant bioavailability and subsequently strengthen or weaken its effects on structural and functional measures (Peters et al. 2013, Ferreira et al. 2016). Moreover, habitat heterogeneity can lead to different structural and functional responses at different sites (Robinson et al. 1998). For example, Collier et al. (2013) showed the influence of small-scale spatial variation in physical conditions on macroinvertebrate abundances and organic-matter breakdown rates. Characteristics of sitespecific organic matter may also influence assessment outcomes. The plant species used in litter-decomposition studies may, for example, affect the relationship observed between structure and function (e.g., LeRoy et al. 2006, Bruder et al. 2014, 2016) because the chemical composition of natural plant material varies within and among both biogeographic regions and leaf species (Lecerf and Chauvet 2008, Graça and Poquet 2014) and can even vary within individual trees (Sariyildiz and Anderson 2003). Variance partitioning analysis could be a valuable approach to partition the influence of these environmental conditions between structural and functional measures in space and time (e.g., Truchy et al. 2019).

\section{CHALLENGES OF COMPARING STRUCTURAL AND FUNCTIONAL RESPONSES IN MULTI- STRESSED ECOSYSTEMS}

Stressors do not usually occur in isolation because most anthropogenic activities cause a multitude of stressors. Focusing on 1 stressor in multi-stressed ecosystems could mean missing other, more important drivers of structural and functional responses (Clapcott et al. 2010). Moreover, interacting stressors may enhance (synergism), lessen (antagonism), or be neutral (additive) in terms of the effects of each individual stressor (Piggott et al. 2015b). To investigate the extent to which multiple stressors affect ecosystem structure and function in comparable ways, we discuss 3 examples of anthropogenic activities that contribute multiple stressors to stream ecosystems: land-use change (e.g., Allan
2004), wastewater-effluent discharge (e.g., Walsh et al. 2005), and hydromorphological alteration (Feld 2004).

\section{Example 1: Land-use change}

Changes in land use can result in the removal of riparian vegetation, nutrient enrichment, sediment addition, flow reduction, and warming (Allan 2004). Each of these stressors may have a different effect on ecosystem structure and function. For example, the removal of riparian vegetation leads to more available light, from which an increase in primary production might be expected. However, removal of vegetation can also decrease primary production through an increase in sediment runoff (Young and Huryn 1999, Frankforter et al. 2010). Sediment loads may limit the growth of primary producers through enhanced movement of sediment (Biggs et al. 1999, Schofield et al. 2004) and increased turbidity, resulting in light limitation (Ryan 1991). The resulting change in algal assemblage may, in turn, reduce the amount and quality of food for herbivorous macroinvertebrates (Townsend and Riley 1999). The removal of riparian vegetation may also limit the distribution of shredders both directly by, for example, removal of egg deposition structures or indirectly by altering the quality of allochthonous inputs with the ultimate result of influencing leaf breakdown rates (Sponseller and Benfield 2001).

Multiple stressors resulting from land-use change can also lead to combinations of interactive effects (i.e., synergistic, additive, and neutral) that complicate our ability to disentangle stressor effects on structural and functional metrics. For example, one study found that sediment addition had mostly negative effects on algal biomass production, leaf-litter decomposition, and invertebrate abundance, and these effects were synergistically enhanced by reduced flow (Matthaei et al. 2010). Two cases of antagonism in agricultural streams were shown by Gücker et al. (2009), where physical stress counteracted the effects of eutrophication by diminishing respiration, and eutrophication counteracted the effects of physical stress by enhancing primary production. In another study, fine sediments weakened the subsidy effect of increased nutrients on algal and invertebrate taxa and communities (Wagenhoff et al. 2011). Additive effects associated with stressors from agricultural land use (i.e., nutrients, a nitrification inhibitor, sedimentation, and flowvelocity reduction) on organic-matter breakdown rates were more common than stressor interactions in a study by Bruder et al. (2016). However, in some cases the synergistic interactive effects of fine-sediment deposition and flow reduction were of the same magnitude as the main stressor effects, here fine-sediment deposition. In other studies, the combined effects of nutrient enrichment and increased temperature were shown to enhance organic-matter breakdown either additively (Piggott et al. 2015a) or synergistically (Ferreira and Chauvet 2011). Nutrient enrichment and fine-sediment input interacted antagonistically to reduce 
organic-matter breakdown, potentially because of reduced microbial access to nutrients and oxygen in the water column (Pascoal et al. 2005, Piggott et al. 2015a).

\section{Example 2: Wastewater treatment plant effluent}

Wastewater treatment plants (WWTPs) generally discharge dissolved nutrients and organic waste along with a suite of toxic substances, like pharmaceuticals and personal care products (Paul and Meyer 2001). Moreover, WWTTP effluents may alter the hydrological and thermal regimes of receiving steams with periodic high-flow events and warmer water temperatures, respectively (e.g., Carey and Migliaccio 2009, Burdon et al. 2020). Depending on the nature of the WWTP effluent, structural and functional measures can be affected positively or negatively. WWTP effluents have been shown to alter the composition of primary producer, microbial heterotroph, and macroinvertebrate assemblages (Hart and Robinson 1990). For example, effluent discharge can cause a decline in macroinvertebrate taxon diversity (Cabrini et al. 2013), whereas the biomass and abundance of certain groups of invertebrates can increase (Muñoz et al. 2009, Alexander et al. 2013) or decrease (Alexander et al. 2013). Likewise, rates of ecosystem processes (e.g., organic-matter breakdown) can also increase (Bundschuh et al. 2009) or decrease (Moreirinha et al. 2011).

The overall impact of WWTPs on structure and function is complex. Dissolved nutrients, organic matter, and warmer water temperatures can subsidize biological activity, whereas toxic substances can be deleterious to organisms and suppress biological activity (Izagirre et al. 2008, Aristi et al. 2015, Burdon et al. 2020). Moreover, the subsidizing effect of enhanced nutrient supply may also be suppressed by reduced light availability caused by the accompanying sediment input, suggesting a stress effect on the activity of primary producers but not the microbial assemblage (Aristi et al. 2015). How these toxic contaminants affect structural and functional measures also depends on local flow conditions. For example, Corcoll et al. (2015) found that long-term exposure to a mixture of pharmaceutical compounds in combination with flow intermittency negatively influenced the structure and metabolism of algal and bacterial communities in biofilms. Algae suffered cumulative effects whereas bacteria showed higher resistance to both stressors, and subsequent production was affected to a greater degree than organic-matter breakdown (Corcoll et al. 2015). A comparable effect was shown by Smeti et al. (2019) where diatom diversity increased across fine-sediment pollution (including persistent organic pollutants, pesticides, and phenolic compounds) and flow-intermittency gradients, whereas both macroinvertebrate diversity and ecosystem functions (resource-use efficiency of primary producers in biofilms and organic-matter breakdown by macroinvertebrates) were negatively affected.

\section{Example 3: Hydromorphological alterations}

One of the most obvious examples of complex multiplestress responses is related to hydromorphological deterioration. Hydromorphological alterations of natural streams are diverse, ranging from the removal of large instream wood to the construction of new artificial channels (Elosegi and Sabater 2013), and bring about a variety of changes in flow and alterations to habitat structure and availability. Changes in primary production due to morphological alteration are dependent on whether the channel's cross-sectional area is increased or decreased, resulting in different patterns in flow velocity, shear stress, and sediment transport (Gücker et al. 2009). These 3 factors are also important determinants of algal and benthic assemblage structure (Poff et al. 1990, Schofield et al. 2004). Increased flow may enhance respiration through the input of organic matter, whereas the transport capacity of organic matter decreases during low-flow events (e.g., Roberts et al. 2007, Val et al. 2016). In other streams, a small reduction in respiration has been observed after floods, and an increase has been observed after droughts (Uehlinger et al. 2003, Acuña et al. 2004, Uehlinger 2006). This difference in respiration response is presumably related to differences in bed substrate stability among streams (Uehlinger and Naegeli 1998). Some researchers have found that the effects of flood-induced scouring on respiration may be limited because microbes are protected from abrasion in the hyporheic zone (Uehlinger and Naegeli 1998, Chester and Norris 2006, Benson et al. 2013). Other authors have reported, however, that after a flood, epiphyton was more productive because of the greater availability of nutrients (Stevenson 1990). In another study, synergistically combined effects of contamination with flow reduction after river damming reduced fungal biomass and taxon diversity, which, in turn, led to reduced shredder performance and leaf-litter decomposition (Colas et al. 2016).

\section{Strategies for assessing multi-stressed ecosystems}

The examples above show that structural and functional responses to multiple anthropogenic stressors can be complex and multidirectional. Anthropogenic effects of 1 stressor can be confounded by changes in another stressor, and both can, in turn, be changed by a $3^{\text {rd }}$ stressor, depending on effects to individual organisms. Thus, quantification of interacting multiple-stressor effects is needed when assessing anthropogenic impacts on ecosystem structure and function. By projecting the contribution of each specific stressor to a multi-stressor space and linking these to the presence and abundance of taxa and ecosystem functions, the drivers of ecosystem response may be elucidated. In addition to considering multiple stressors, it is prudent to consider multiple processes simultaneously because different processes can interact or respond in opposite directions, thereby influencing overall ecosystem function (Giling et al. 2019). 
There are several potential approaches to better understand the effects of multiple stressors on ecosystem structure and function. One approach is an experimental design proposed by Giller et al. (2004) that incorporates a control and 4 different sequences of stressors (stressors A and B) with several sampling dates: before application of the stressors, after the $1^{\text {st }}$ application of stressors (e.g., $1^{\text {st }}$ treatment $1-5$ with application of stressors A, B, A, B, control, respectively), after the $2^{\text {nd }}$ application of stressors (e.g., $2^{\text {nd }}$ treatment $1-$ 5 with application of stressors B, A, A, B, control, respectively, and on additional occasions after the $2^{\text {nd }}$ application. This experimental design allows testing how different species assemblages and associated ecological processes respond to 2 sequences of different types of stress $(\mathrm{AB}, \mathrm{BA})$ and 2 sequences of the same types of stress (AA, BB), as well as their subsequent recovery patterns. Another approach for disentangling the effects of multiple stressors on ecosystem structure and function is the use of extensive statistical analysis on large datasets. For instance, Feld et al. (2016) presented a protocol that describes how to rank multiple stressors' importance (e.g., using random forest analysis), detect relevant interactions (e.g., using boosted regression tree analysis), and estimate their standardized effect size (e.g., using generalized linear modeling) from a dataset with a minimum of 150 independent observations that cover the most relevant stressors' gradients. A $3^{\text {rd }}$ approach is the use of ecological network theory as described by Bruder et al. (2019). Rather than measuring the direct effects of stressors on structural and functional measures as independent endpoints, ecological networks focus on the biotic (trophic and non-trophic) and environmental interactions. They proposed that quantifying these network characteristics using structural equation modeling can show the direct and indirect impacts of multiple stressors on organisms, communities, and ecosystem processes.

\section{FUNCTIONAL ROLES OF SPECIES}

The effects of stressors on ecosystem processes are often dictated by effects on structural measures, such as community composition (Truchy et al. 2019). In general, environmental stressors can mediate structure-function relationships by either suppressing the role of a dominant taxon or by decreasing species diversity (Cardinale and Palmer 2002). Understanding species' roles in ecosystem processes is, therefore, critical for assessing ecological consequences of anthropogenic stressors (Dangles and Guerold 2001, Carlisle and Clements 2005).

\section{Dominant taxa in key functional roles}

One way that the presence of dominant taxa can influence the effect of a stressor on ecological processes is via process rates (e.g., Dangles and Malmqvist 2004). This effect is primarily associated with the role shredders play in determining the rate of litter decomposition under different types of stressors. Shredder species can differ substantially in the rate that they break down organic matter (Dangles and Guerold 2001), which has been shown by multiple leaf-litter decomposition studies where the effects of stressors on specific species of amphipods (Dangles and Guerold 2001, Dangles et al. 2004, Lecerf et al. 2006, Piscart et al. 2009, Rasmussen et al. 2012), isopods (Bergfur et al. 2007), caddisflies (Robinson et al. 1998, McKie et al. 2006), and stoneflies (Carlisle and Clements 2005) led to differences in organic-matter breakdown rates. Even minor changes in community composition, such as the loss or replacement of a single dominant species, can lead to disproportionate changes in organic-matter breakdown rates (e.g., Carlisle and Clements 2005, Lecerf et al. 2006, Bergfur et al. 2007). For example, Dangles and Guerold (2000) demonstrated that acidification significantly changed litter breakdown rates in an upland stream because of the difference in acid tolerance between the stonefly Protonemura spp. (low shredding rates) and the amphipod Gammarus spp. (high shredding rates).

\section{Diversity meets function}

Taxonomic diversity of shredders has also been shown to be key in driving organic-matter breakdown rates (e.g., Huryn et al. 2002, Jonsonn et al. 2002, Jonsson and Malmqvist 2003). One experimental study showed that increased species diversity enhanced organic-matter breakdown rates, even when all species belonged to the same guild (Jonsson and Malmqvist 2000). Four potential mechanisms have been suggested to explain how increased species diversity can enhance organic-matter breakdown rates and offset the effects of stressors: 1) complementary resource use (e.g., a combination of different feeding strategies, life cycles, and substrate and current-velocity preferences; Frainer et al. 2014), 2) facilitation between species (Tiunov and Schue 2005), 3) fewer negative interactions between species (i.e., behavioral interactions might occur less often in diverse communities, allowing more time to be spent on feeding; Jonsson and Malmqvist 2000), and 4) the insurance effect (i.e., diverse communities are more likely to include tolerant species, which are able to compensate for those species negatively affected by a given stressor; Loreau 2002, McKie et al. 2009). The ability of tolerant species to replace sensitive species in response to stressors while maintaining or even enhancing a particular ecosystem function is particularly evident for microorganisms (Masseret et al. 1998, Blanck 2002, Corcoll et al. 2015, Feckler et al. 2018) but has also been shown for invertebrates (e.g., Woodcock and Huryn 2005).

\section{Non-trophic roles}

In addition to functional roles based on trophic interactions, there are also non-trophic functional roles that may play an important, but largely unknown, role in ecosystem 
function (Jones et al. 1994, Wright and Jones 2006, Kéfi et al. 2012, Dussault 2019). For example, ecosystem engineers (i.e., organisms that directly or indirectly physically modulate the availability of resources to other species and thereby alter environmental and ecological processes) provide non-trophic roles in ecosystem functions (Jones et al. 1994, 2010, Wright and Jones 2006, Gutiérrez et al. 2014). Autogenous ecosystem engineers are organisms that modify the environment with their own living or non-living structures. Macrophytes, for instance, create physical habitat with their tissue, affect light, oxygen, and temperature regimes, and alter sedimentation rates (Jones et al. 1994). Other organisms, allogenous engineers, change the environment by transforming living and non-living matter from one physical state to another, such as beavers that cut down trees to construct dams and burrowing organisms that actively rework soils (Jones et al. 1994, Anderson and Rosemond 2007). The roles of these ecosystem engineers in ecosystem function have received limited attention in empirical studies compared with trophic interactions (Lévêque 2003, Wright and Jones 2006, Borst et al. 2018). A recent example by Puche et al. (2020) offered preliminary evidence that the inclusion of non-trophic roles in ecological models may be crucial to better understand the functioning of complex communities and their responses to stressors. Specifically, they composed a network model based on mesocosmexperiment data with 3 coupled habitats (pelagic, withinmeadow, and benthic) subjected to 3 environmental scenarios (warming, increased ultraviolet radiation, and control). Adding non-trophic roles changed the relevance of habitats and the trophic interactions within them (Puche et al. 2020). Future studies including field data could provide further evidence of the importance of these largely unknown nontrophic roles for ecosystem functioning.

\section{FUTURE PERSPECTIVES ON STREAM ASSESSMENT}

Effective water management requires action and prediction based on diagnostic information. Mechanistic understanding of ecosystem structure and related processes can support managers in making stronger inferences about the effects of stressors on ecosystem integrity (Elosegi et al. 2017). Much is known about single stressors causing reductions in the density of key functional dominant species and causing losses of sensitive indicator species. Less is known about the complex interactions among multiple stressors and their effects on species and, therefore, their trophic and non-trophic contributions to ecosystem functions. Furthermore, there is a great deal more available qualitative than quantitative information about structural and functional responses to multiple-stressor interactions. Because quantitative knowledge is needed for effective, integrated water management, we propose that there is a need 1) to increase understanding of the roles of individual species and communities in stream ecosystem function and 2) to quantify the responses of individual species and communities to individual stressors and combinations of multiple stressors.

\section{Understanding suites of interacting traits}

Single-trait approaches to understanding the roles of individual species in stream-ecosystem function have been largely unsuccessful (Hamilton et al. 2020). Potentially, using an evolutionary perspective on the coevolution of functional traits in response to natural selection could improve our understanding of species' functional roles (Southwood 1977, Grime 1979, Winemiller 1992). Selection pressures do not act independently on single traits but, rather, act on species with a suite of multiple interacting traits (Pilière et al. 2016). The adaptive value of a particular trait may differ within and across species depending on its life stage, other traits possessed by the species, and the prevailing environmental conditions (Statzner and Bêche 2010, Rubach et al. 2011, Wilkes et al. 2017). A species' plasticity in resource requirements enlarges its fundamental niche, and plasticity in the proportional resource uptake results in expansion of the realized niche (Berg and Ellers 2010). Both enlarge the adaptive value of a trait and thereby strengthen the functional role of a species within a community. Local environmental (abiotic and biotic) conditions, thus, determine the structure and function of a local community (Leibold et al. 2004). Knowledge about suites of interacting traits that evolved under local environmental conditions (including multiple-stressor effects) would help us better understand ecosystem structure and function (Leibold et al. 2004, Hamilton et al. 2020).

The tolerance of species traits to 1 environmental factor (or stressor) can affect the response of communities and functional groups to other stressors. An environmentalfactor-induced shift in a single or multiple trait adaptation by natural selection will strengthen positive co-tolerance among taxa, and a lack of such exposure and adaptation can be expected to decrease co-tolerance and reduce resistance (Vinebrooke et al. 2004). This reasoning applies not only to macroinvertebrates but can be projected on many organism groups, including microbes (e.g., McGhee 2011, Winemiller et al. 2015). Development of molecular technology that allows for identification and characterization of the functional traits of microbial assemblages may add to a better understanding of ecosystem function (Sims et al. 2013). However, most response and effect traits are based on several interacting genes that are difficult to understand in combination. Moreover, many genes indicative of a trait might not be expressed; therefore, although they might be identified by DNA-mining approaches, they may be irrelevant for determining local ecosystem structure and function.

\section{Using multiple traits to assess ecosystem function}

Improved knowledge on multiple trait-based species or species-assemblage sensitivities to specific stressors would 
help quantify the response of individual species and communities to individual stressors and combinations of multiple stressors. A quantitative approach requires a targeted selection of physiological, behavioral, or life-cycle traits, i.e., traits that have a clear mechanistic relationship with different stressors (fundamental determinants of intrinsic sensitivity) and the processes induced by the stressors (e.g., Rubach et al. 2010, Ippolito et al. 2012). Several recent studies have addressed multiple important traits (e.g., Poff and Allan 1995, Lamouroux et al. 2004), but there has been little emphasis on the traits or trait combinations that are relevant for ecosystem function. A direct emphasis on the quantitative relationships between traits, groups of traits, or multiple interconnected trait types (functional types) and ecosystem processes might further increase our understanding of ecosystem function (e.g., Harvey et al. 2017, Seibold et al. 2018, Delmas et al. 2019). Changes in species assemblages, such as the disappearance of a single species resulting from an environmental change, could cause the loss of a functional type, which would lead to a change in ecosystem function or could affect the functioning of other species in the same assemblage.

The influence of evolutionary history, or phylogeny, on suites of functional traits that shape key ecosystem processes is another area of research that could further strengthen functional assessment in multi-stressed stream ecosystems. Leroy et al. (2020) demonstrated that plant phylogeny was a critically important predictor of litter decomposition rates in rivers and streams, explaining more of the variance in decomposition than was explained by site or climatic regime. In another study the relationship between phylogenetic diversity and productivity appeared to be strong for ancestral microbial lineages but weakened for the evolved lineages (Gravel et al. 2012). Both studies emphasized the potential of using species' evolutionary histories to evaluate ecosystem function. Saito et al. (2015) went a step further by including phylogenetic constraints to functional assessment. They reasoned that a community with species from different taxonomical lineages will be more ecologically diverse than an assemblage composed of phylogenetically close neighbors because the latter is likely to have evolved similar phenotypes and traits through niche conservatism (Saito et al. 2016). Webb et al. (2002) proposed integrating phylogenetic information into future studies by examining the phylogenetic structure of assemblages and exploring the phylogenetic basis of assemblage niche structure.

We conclude that structural and functional responses can be similar or contradictory in magnitude and direction both within and between studies in stream ecosystems. Moreover, impacts from a combination of multiple interacting stressors on ecosystem structure and function are often complex. In these cases structural and functional measures can be considered complementary and should be used in concert to capture a broad range of potential effects and to provide insights into the functional consequences of changes in community structure. Trait-based knowledge is further needed to understand the relationship between structure and function in multi-stressed stream ecosystems and could help managers to make stronger inferences about the effects of these stressors on water quality and status.

\section{ACKNOWLEDGEMENTS}

Author contributions: PFM and GHvdL contributed equally to the manuscript.

We thank editor-in-chief Charles Hawkins, associate editor Christoph Matthaei, technical editor Brooke Cassell, Ralf Verdonschot, and 2 anonymous reviewers for their helpful comments and suggestions. This research was part of the Smart Monitoring Project (443.324) and was funded by the Foundation for Applied Water Research.

\section{LITERATURE CITED}

Acuña, V., A. Giorgi, I. Muñoz, U. R. S. Uehlinger, and S. Sabater. 2004. Flow extremes and benthic organic matter shape the metabolism of a headwater Mediterranean stream. Freshwater Biology 49:960-971.

Acuña, V., I. Muñoz, A. Giorgi, M. Omella, F. Sabater, and S. Sabater. 2005. Drought and postdrought recovery cycles in an intermittent Mediterranean stream: Structural and functional aspects. Journal of the North American Benthological Society 24:919-933.

Acuña, V., C. Vilches, and A. Giorgi. 2010. As productive and slow as a stream can be-The metabolism of a Pampean stream. Journal of the North American Benthological Society 30:71-83.

Alexander, A. C., A. T. Luis, J. M. Culp, D. J. Baird, and A. J. Cessna. 2013. Can nutrients mask community responses to insecticide mixtures? Ecotoxicology 22:1085-1100.

Allan, E. L., P. W. Froneman, and A. N. Hodgson. 2006. Effects of temperature and salinity on the standard metabolic rate (SMR) of the caridean shrimp Palaemon peringueyi. Journal of Experimental Marine Biology and Ecology 337:103-108.

Allan, J. D. 2004. Landscapes and riverscapes: The influence of land use on stream ecosystems. Annual Review of Ecology, Evolution, and Systematics 35:257-284.

Anderson, C. B., and A. D. Rosemond. 2007. Ecosystem engineering by invasive exotic beavers reduces in-stream diversity and enhances ecosystem function in Cape Horn, Chile. Oecologia 154:141-153.

Aristi, I., D. von Schiller, M. Arroita, D. Barceló, L. Ponsatí, M. J. García-Galán, S. Sabater, A. Elosegi, and V. Acuña. 2015. Mixed effects of effluents from a wastewater treatment plant on river ecosystem metabolism: Subsidy or stress? Freshwater Biology 60:1398-1410.

Bailey, R. C., R. H. Norris, and T. B. Reynoldson. 2004. Bioassessment of freshwater ecosystems: Using the reference condition approach. Kluwer Academic Publishers, Boston, Massachusetts.

Barko, J. W., M. S. Adams, and N. L. Clesceri. 1986. Environmental factors and their consideration in the management of submersed aquatic vegetation: A review. Journal of Aquatic Plant Management 24:1-10.

Bärlocher, F., and M. Corkum. 2003. Nutrient enrichment overwhelms diversity effects in leaf decomposition by stream fungi. Oikos 101:247-252. 
Benson, E. R., M. S. Wipfli, J. E. Clapcott, and N. F. Hughes. 2013. Relationships between ecosystem metabolism, benthic macroinvertebrate densities, and environmental variables in a subarctic Alaskan river. Hydrobiologia 701:189-207.

Berg, M. P., and J. Ellers. 2010. Trait plasticity in species interactions: A driving force of community dynamics. Evolutionary Ecology 24:617-629.

Bergfur, J., R. K. Johnson, L. Sandin, W. Goedkoop, and K. Nygren. 2007. Effects of nutrient enrichment on boreal streams: Invertebrates, fungi and leaf-litter breakdown. Freshwater Biology 52:1618-1633

Bernot, M. J., D. J. Sobota, R. O. Hall, P. J. Mulholland, W. K. Dodds, J. R. Webster, J. L. Tank, L. R. Ashkenas, L. W. Cooper, C. N. Dahm, S. V. Gregory, N. B. Grimm, S. K. Hamilton, S. L. Johnson, W. H. McDowell, J. L. Meyer, B. Peterson, G. C. Poole, H. M. Valett, C. Arango, J. J. Beaulieu, A. J. Burgin, C. Crenshaw, A. M. Helton, L. Johnson, J. Merriam, B. R. Niederlehner, J. M. O’Brien, J. D. Potter, R. W. Sheibley, S. M. Thomas, and K. Wilson. 2010. Inter-regional comparison of land-use effects on stream metabolism. Freshwater Biology 55:1874-1890.

Biggs, B. J. F., R. A. Smith, and M. J. Duncan. 1999. Velocity and sediment disturbance of periphyton in headwater streams: Biomass and metabolism. Journal of the North American Benthological Society 18:222-241.

Birk, S., W. Bonne, A. Borja, S. Brucet, A. Courrat, S. Poikane, A. Solimini, W. van de Bund, N. Zampoukas, and D. Hering. 2012. Three hundred ways to assess Europe's surface waters: An almost complete overview of biological methods to implement the Water Framework Directive. Ecological Indicators 18: $31-41$.

Blanck, H. 2002. A critical review of procedures and approaches used for assessing pollution-induced community tolerance (PICT) in biotic communities. Human and Ecological Risk Assessment 8:1003-1034.

Borst, A. C. W., W. C. E. P. Verberk, C. Angelini, J. Schotanus, J. W. Wolters, M. J. A. Christianen, E. M. van der Zee, M. Derksen-Hoojiberg, and T. van der Heide. 2018. Foundation species enhance food web complexity through non-trophic facilitation. PloS ONE 13:e0199152.

Bott, T. L., D. S. Montgomery, J. D. Newbold, D. B. Arscott, C. L. Dow, A. K. Aufdenkampe, J. K. Jackson, and L. A. Kaplan. 2006. Ecosystem metabolism in streams of the Catskill Mountains (Delaware and Hudson River watersheds) and lower Hudson Valley. Journal of the North American Benthological Society 25:1018-1044.

Boulton, A. J. 1999. An overview of river health assessment: Philosophies, practice, problems and prognosis. Freshwater Biology 41:469-479.

Bruder, A., A. Frainer, T. Rota, and R. Primicerio. 2019. The importance of ecological networks in multiple-stressor research and management. Frontiers in Environmental Science 7:59.

Bruder, A., R. K. Salis, N. J. McHugh, and C. D. Matthaei. 2016. Multiple-stressor effects on leaf litter decomposition and fungal decomposers in agricultural streams contrast between litter species. Functional Ecology 30:1257-1266.

Bruder, A., M. H. Schindler, M. S. Moretti, and M. O. Gessner. 2014. Litter decomposition in a temperate and a tropical stream: The effects of species mixing, litter quality and shredders. Freshwater Biology 59:438-449.
Bukaveckas, P. A. 2007. Effects of channel restoration on water velocity, transient storage, and nutrient uptake in a channelized stream. Environmental Science \& Technology 41:1570-1576.

Bundschuh, M., T. Hahn, M. O. Gessner, and R. Schulz. 2009. Antibiotics as a chemical stressor affecting an aquatic decomposer-detritivore system. Environmental Toxicology and Chemistry 28:197-203.

Burdon, F. J., Y. Bai, M. Reyes, M. Tamminen, P. Staudacher, S. Mangold, H. Singer, K. Räsänen, A. Joss, S. D. Tiegs, J. Jokela, R. I. L. Eggen, and C. Stamm. 2020. Stream microbial communities and ecosystem functioning show complex responses to multiple stressors in wastewater. Global Change Biology early view. (Available from: https://doi.org/10.1111/gcb.15302)

Burson, A., M. Stomp, E. Greenwell, J. Grosse, and J. Huisman. 2018. Competition for nutrients and light: Testing advances in resource competition with a natural phytoplankton community. Ecology 99:1108-1118.

Cabrini, R., S. Canobbio, L. Sartori, R. Fornaroli, and V. Mezzanotte. 2013. Leaf packs in impaired streams: The influence of leaf type and environmental gradients on breakdown rate and invertebrate assemblage composition. Water, Air, \& Soil Pollution 224:1967-1979.

Cardinale, B. J., and M. A. Palmer. 2002. Disturbance moderates biodiversity-ecosystem function relationships: Experimental evidence from caddisflies in stream mesocosms. Ecology 83: 1915-1927.

Cardinale, B. J., M. A. Palmer, and S. L. Collins. 2002. Species diversity enhances ecosystem functioning through interspecific facilitation. Nature 415:426-429.

Carey, R. O., and K. W. Migliaccio. 2009. Contribution of wastewater treatment plant effluents to nutrient dynamics in aquatic systems: A review. Environmental Management 44:205-217.

Carlisle, D. M., and W. H. Clements. 2005. Leaf litter breakdown, microbial respiration and shredder production in metalpolluted streams. Freshwater Biology 50:380-390.

Castela, J., V. Ferreira, and M. A. S. Graça. 2008. Evaluation of stream ecological integrity using litter decomposition and benthic invertebrates. Environmental Pollution 153:440-449.

Chaffin, J. L., H. M. Valett, J. R. Webster, and M. E. Schreiber. 2005. Influence of elevated As on leaf breakdown in an Appalachian headwater stream. Journal of the North American Benthological Society 24:553-568.

Chauvet, E. 1997. Leaf litter decomposition in large rivers: The case of the River Garonne. Limnetica 13:65-70.

Chester, H., and R. Norris. 2006. Dams and flow in the Cotter River, Australia: Effects on instream trophic structure and benthic metabolism. Hydrobiologia 572:275-286.

Clapcott, J. E., K. J. Collier, R. G. Death, E. O. Goodwin, J. S. Harding, D. Kelly, J. R. Leathwick, and R. G. Young. 2012. Quantifying relationships between land-use gradients and structural and functional indicators of stream ecological integrity. Freshwater Biology 57:74-90.

Clapcott, J. E., R. G. Young, E. O. Goodwin, and J. R. Leathwick. 2010. Exploring the response of functional indicators of stream health to land-use gradients. Freshwater Biology 55: 2181-2199.

Colas, F., J. M. Baudoin, E. Chauvet, H. Clivot, M. Danger, F. Guérold, and S. Devin. 2016. Dam-associated multiple-stressor impacts on fungal biomass and richness reveal the initial signs 
of ecosystem functioning impairment. Ecological Indicators 60:1077-1090.

Collier, K. J., J. E. Clapcott, I. C. Duggan, D. P. Hamilton, M. Hamer, and R. G. Young. 2013. Spatial variation of structural and functional indicators in a large New Zealand river. River Research and Applications 29:1277-1290.

Corcoll, N., M. Casellas, B. Huerta, H. Guasch, V. Acuña, S. Rodríguez-Mozaz, A. Serra-Compte, D. Barcelo, and S. Sabater. 2015. Effects of flow intermittency and pharmaceutical exposure on the structure and metabolism of stream biofilms. Science of the Total Environment 503:159-170.

Crossey, M. J., and T. W. La Point. 1988. A comparison of periphyton community structural and functional responses to heavy metals. Hydrobiologia 162:109-121.

Cummins, K. W., and M. J. Klug. 1979. Feeding ecology of stream invertebrates. Annual Review of Ecology and Systematics 10: 147-172.

Dale, V. H., and S. C. Beyeler. 2001. Challenges in the development and use of ecological indicators. Ecological Indicators $1: 3-10$.

Dang, C. K., M. Schindler, E. Chauvet, and M. O. Gessner. 2009. Temperature oscillation coupled with fungal community shifts can modulate warming effects on litter decomposition. Ecology 90:122-131.

Dangles, O., M. O. Gessner, F. Guérold, and E. Chauvet. 2004. Impacts of stream acidification on litter breakdown: Implications for assessing ecosystem functioning. Journal of Applied Ecology 41:365-378.

Dangles, O., and F. Guérold. 2001. Influence of shredders in mediating breakdown rates of beech leaves in circumneutral and acidic forest streams. Archiv für Hydrobiologie 151:649-666.

Dangles, O., and B. Malmqvist. 2004. Species richness-decomposition relationships depend on species dominance. Ecology Letters 7:395-402.

Dangles, O. J., and F. A. Guérold. 2000. Structural and functional responses of benthic macroinvertebrates to acid precipitation in two forested headwater streams (Vosges Mountains, northeastern France). Hydrobiologia 418:25-31.

Death, R. G., Z. S. Dewson, and A. B. W. James. 2009. Is structure or function a better measure of the effects of water abstraction on ecosystem integrity? Freshwater Biology 54:2037-2050.

Delmas, E., M. Besson, M. H. Brice, L. A. Burkle, G. V. Dalla Riva, M. J. Fortin, D. Gravel, P. R. Guimarães Jr, D. H. Hembry, E. A. Newman, J. M. Olesen, M. M. Pires, J. D. Yeakel, and T. Poisot. 2019. Analysing ecological networks of species interactions. Biological Reviews 94:16-36.

Dewson, Z. S., A. B. W. James, and R. G. Death. 2007. A review of the consequences of decreased flow for instream habitat and macroinvertebrates. Journal of the North American Benthological Society 26:401-415.

Dodds, W. K. 2006. Eutrophication and trophic state in rivers and streams. Limnology and Oceanography 51:671-680.

Dolédec, S., B. Statzner, and M. Bournaud. 1999. Species traits for future biomonitoring across ecoregions: Patterns along a human-impacted river. Freshwater Biology 42:737-758.

Dunck, B., E. Lima-Fernandes, F. Cássio, A. Cunha, L. Rodrigues, and C. Pascoal. 2015. Responses of primary production, leaf litter decomposition and associated communities to stream eutrophication. Environmental Pollution 202:32-40.
Dussault, A. C. 2019. Functional biodiversity and the concept of ecological function. Pages 297-316 in E. Casetta, J. Marques da Silva, and D. Vecchi (editors). From assessing to conserving biodiversity: Conceptual and practical challenges. History, philosophy and theory of the life sciences, volume 24. Springer, Cham, Switzerland.

Elosegi, A., M. O. Gessner, and R. G. Young. 2017. River doctors: Learning from medicine to improve ecosystem management. Science of the Total Environment 595:294-302.

Elosegi, A., and S. Sabater. 2013. Effects of hydromorphological impacts on river ecosystem functioning: A review and suggestions for assessing ecological impacts. Hydrobiologia 712:129-143.

Feckler, A., W. Goedkoop, M. Konschak, R. Bundschuh, K. G. Kenngott, R. Schulz, J. P. Zubrod, and M. Bundschuh. 2018. History matters: Heterotrophic microbial community structure and function adapt to multiple stressors. Global Change Biology 24:402-415.

Feio, M. J., T. Alves, M. Boavida, A. Medeiros, and M. A. S Graça. 2010. Functional indicators of stream health: A river-basin approach. Freshwater Biology 55:1050-1065.

Feld, C. K. 2004. Identification and measure of hydromorphological degradation in central European lowland streams. Pages 69-90 in D. Hering, P. F. M. Verdonschot, O. Moog, and L. Sandin (editors). Integrated assessment of running water in Europe. Springer Science+Business Media, Dordrecht, The Netherlands.

Feld, C. K., P. Segurado, and C. Gutiérrez-Cánovas. 2016. Analysing the impact of multiple stressors in aquatic biomonitoring data: A 'cookbook' with applications in R. Science of the Total Environment 573:1320-1339.

Fellows, C. S., J. E. Clapcott, J. W. Udy, S. E. Bunn, B. D. Harch, M. J. Smith, and P. M. Davies. 2006. Benthic metabolism as an indicator of stream ecosystem health. Hydrobiologia 572:71-87.

Ferreira, V., and E. Chauvet. 2011. Synergistic effects of water temperature and dissolved nutrients on litter decomposition and associated fungi. Global Change Biology 17:551-564.

Ferreira, V., A. Elosegi, V. Gulis, J. Pozo, and M. A. Graça. 2006 . Eucalyptus plantations affect fungal communities associated with leaf-litter decomposition in Iberian streams. Archiv für Hydrobiologie 166:467-490.

Ferreira, V., M. A. Graça, J. L. de Lima, and R. Gomes. 2006b. Role of physical fragmentation and invertebrate activity in the breakdown rate of leaves. Archiv für Hydrobiologie 165:493-513.

Ferreira, V., J. Koricheva, S. Duarte, D. K. Niyogi, and F. Guérold. 2016. Effects of anthropogenic heavy metal contamination on litter decomposition in streams-A meta-analysis. Environmental Pollution 210:261-270.

Frainer, A., and B. G. McKie. 2015. Shifts in the diversity and composition of consumer traits constrain the effects of land use on stream ecosystem functioning. Pages 169-200 in S. Pawar, G. Woodward, and A. I. Dell (editors). Trait-based ecologyFrom structure to function. Advances in ecological research, volume 52. Academic Press, Waltham, Massachusetts.

Frainer, A., B. G. McKie, and B. Malmqvist. 2014. When does diversity matter? Species functional diversity and ecosystem functioning across habitats and seasons in a field experiment. Journal of Animal Ecology 83:460-469.

Frankforter, J. D., H. S. Weyers, J. D. Bales, P. W. Moran, and D. L. Calhoun. 2010. The relative influence of nutrients and habitat 
on stream metabolism in agricultural streams. Environmental Monitoring and Assessment 168:461-479.

Friberg, N., J. B. Dybkjær, J. S. Olafsson, G. M. Gislason, S. E. Larsen, and T. L. Lauridsen. 2009. Relationships between structure and function in streams contrasting in temperature. Freshwater Biology 54:2051-2068.

Gelroth, J. V., and G. R. Marzolf. 1978. Primary production and leaf-litter decomposition in natural and channelized portions of a Kansas stream. American Midland Naturalist 99:238-243.

Gessner, M. O., and E. Chauvet. 2002. A case for using litter breakdown to assess functional stream integrity. Ecological Applications 12:498-510.

Giling, D. P., L. Beaumelle, H. R. P. Phillips, S. Cesarz, N. Eisenhauer, O. Ferlian, F. Gottschall, C. Guerra, J. Hines, A. Sendek, J. Siebert, M. P. Thakur, and A. D. Barnes. 2019. A niche for ecosystem multifunctionality in global change research. Global Change Biology 25:763-774.

Giller, P. S., H. Hillebrand, U. G. Berninger, M. O. Gessner, S. Hawkins, P. Inchausti, C. Inglis, H. Leslie, B. Malmqvist, M. T. Monaghan, P. J. Morin, and G. O'Mullan. 2004. Biodiversity effects on ecosystem functioning: Emerging issues and their experimental test in aquatic environments. Oikos 104: 423-436.

González, J. M., S. Mollá, N. Roblas, E. Descals, O. Moya, and C. Casado. 2013. Small dams decrease leaf litter breakdown rates in Mediterranean mountain streams. Hydrobiologia 712:117128 .

Graça, M. A. S., and J. M. Poquet. 2014. Do climate and soil influence phenotypic variability in leaf litter, microbial decomposition and shredder consumption? Oecologia 174:1021-1032.

Gravel, D., T. Bell, C. Barbera, M. Combe, T. Pommier, and N. Mouquet. 2012. Phylogenetic constraints on ecosystem functioning. Nature Communications 3:1-6.

Grime, J. P. 1979. Plant strategies and vegetation processes. John Wiley and Sons, New York, New York.

Gücker, B., I. G. Boechat, and A. Giani. 2009. Impacts of agricultural land use on ecosystem structure and whole-stream metabolism of tropical Cerrado streams. Freshwater Biology 54: 2069-2085.

Gücker B., M. Brauns, and M. T. Pusch. 2006. Effects of wastewater plant discharge on ecosystem structure and function in lowland streams. Journal of the North American Benthological Society 25:313-329.

Gulis, V., V. Ferreira, and M. A. S. Graça. 2006. Stimulation of leaf litter decomposition and associated fungi and invertebrates by moderate eutrophication: Implications for stream assessment. Freshwater Biology 51:1655-1669.

Gulis, V., and K. Suberkropp. 2003. Leaf litter decomposition and microbial activity in nutrient-enriched and unaltered reaches of a headwater stream. Freshwater Biology 48:123-134.

Gutiérrez, J. L., C. G. Jones, and R. Sousa. 2014. Toward an integrated ecosystem perspective of invasive species impacts. Acta Oecologica 54:131-138.

Hagen, E. M., J. R. Webster, and E. F. Benfield. 2006. Are leaf breakdown rates a useful measure of stream integrity along an agricultural land-use gradient? Journal of the North American Benthological Society 25:330-343.

Hamilton, A. T., R. B. Schäfer, M. I. Pyne, B. Chessman, K. Kakouie, K. S. Boersma, P. F. M. Verdonschot, R. C. M. Verdonschot, M.
Mims, K. Khamis, B. Bierwagen, and J. Stamp. 2020. Limitations of trait-based approaches for stressor assessment: The case of freshwater invertebrates and climate drivers. Global Change Biology 26:364-379.

Hart, D. D., and C. T. Robinson. 1990. Resource limitation in a stream community: Phosphorus enrichment effects on periphyton and grazers. Ecology 71:1494-1502.

Harvey, E., I. Gounand, C. L. Ward, and F. Altermatt. 2017. Bridging ecology and conservation: From ecological networks to ecosystem function. Journal of Applied Ecology 54:371-379.

Hill, W. R., P. J. Mulholland, and E. R. Marzolf. 2001. Stream ecosystem responses to forest leaf emergence in spring. Ecology 82:2306-2319.

Hladyz, S., K. Åbjörnsson, E. Chauvet, M. Dobson, A. Elosegi, V. Ferreira, T. Fleituch, M. O. Gessner, P. S. Giller, V. Gulis, S. A. Hutton, J. O. Lacoursière, S. Lamothe, A. Lecerf, B. Malmqvist, B. G. McKie, M. Nistorescu, E. P. Miira, P. Riipinen, G. Rîşnoveanu, M. Schindler, S. D. Tiegs, L. B. M. Vought, and G. Woodward. 2011a. Stream ecosystem functioning in an agricultural landscape: The importance of terrestrial-aquatic linkages. Advances in Ecological Research 44:211-276.

Hladyz, S., K. Åbjörnsson, P. S. Giller, and G. Woodward. 2011b. Impacts of an aggressive riparian invader on community structure and ecosystem functioning in stream food webs. Journal of Applied Ecology 48:443-452.

Huryn, A. D., V. M. Butz Huryn, C. J. Arbuckle, and L. Tsomides. 2002. Catchment land-use, macroinvertebrates and detritus processing in headwater streams: Taxonomic richness versus function. Freshwater Biology 47:401-415.

Hynes, H. B. N. 1960. The biology of polluted waters. Liverpool University Press, Liverpool, United Kingdom.

Ippolito, A., R. Todeschini, and M. Vighi. 2012. Sensitivity assessment of freshwater macroinvertebrates to pesticides using biological traits. Ecotoxicology 21:336-352.

Izagirre O., U. Agirre, M. Bermejo, J. Pozo, and A. Elosegi. 2008. Environmental controls of whole-stream metabolism identified from continuous monitoring of Basque streams. Journal of the North American Benthological Society 27:252-268.

Jones, C. G., J. L. Gutiérrez, J. E. Byers, J. A. Crooks, J. G. Lambrinos, and T. S. Talley. 2010. A framework for understanding physical ecosystem engineering by organisms. Oikos 119:1862-1869.

Jones, C. G., J. H. Lawton, and M. Shachak. 1994. Organisms as ecosystem engineers. Oikos 69:373-386.

Jonsson, M., O. Dangles, B. Malmqvist, and F. Gueérold. 2002. Simulating species loss following perturbation: Assessing the effects on process rates. Proceedings of the Royal Society of London B: Biological Sciences 269:1047-1052.

Jonsson, M., and B. Malmqvist. 2000. Ecosystem process rate increases with animal species richness: Evidence from leaf-eating, aquatic insects. Oikos 89:519-523.

Jonsson, M., and B. Malmqvist. 2003. Mechanisms behind positive diversity effects on ecosystem functioning: Testing the facilitation and interference hypotheses. Oecologia 34:554559.

Karr, J. R. 1999. Defining and measuring river health. Freshwater Biology 41:221-234.

Kéfi, S., E. L. Berlow, E. A. Wieters, S. A. Navarrete, O. L. Petchey, S. A. Wood, A. Boit, L. N. Joppa, K. D. Lafferty, R. J. Williams, 
N. D. Martinez, B. A. Menge, C. A. Blanchette, A. C. Iles, and U. Brose. 2012. More than a meal-Integrating non-feeding interactions into food webs. Ecology Letters 15:291-300.

Lamouroux, N., S. Dolédec, and S. Gayraud. 2004. Biological traits of stream macroinvertebrate communities: Effects of microhabitat, reach, and basin filters. Journal of the North American Benthological Society 23:449-466.

Lecerf, A., and E. Chauvet. 2008. Diversity and functions of leafdecaying fungi in human-altered streams. Freshwater Biology 53:1658-1672.

Lecerf, A., P. Usseglio-Polatera, J. Charcosset, D. Lambrigot, B. Bracht, and E. Chauvet. 2006. Assessment of functional integrity of eutrophic streams using litter breakdown and benthic macroinvertebrates. Archiv für Hydrobiologie 165:105-126.

Leggieri, L., C. Feijoó, A. Giorgi, N. Ferreiro, and V. Acuña. 2013. Seasonal weather effects on hydrology drive the metabolism of non-forest lowland streams. Hydrobiologia 716:47-58.

Leibold, M. A., M. Holyoak, N. Mouquet, P. Amarasekare, J. M. Chase, M. F. Hoopes, R. D. Holt, J. B. Shurin, R. Law, D. Tilman, M. Loreau, and A. Gonzalez. 2004. The metacommunity concept: A framework for multi-scale community ecology. Ecology Letters 7:601-613.

LeRoy, C. J., A. L. Hipp, K. Lueders, J. J. Follstad Shah, J. S. Kominoski, M. Ardón, W. K. Dodds, M. O. Gessner, N. A. Griffiths, A. Lecerf, D. W. P. Manning, R. L. Sinsabaugh, and J. R. Webster. 2020. Plant phylogenetic history explains in-stream decomposition at a global scale. Journal of Ecology 108:17-35.

LeRoy, C. J., T. G. Whitham, P. Keim, and J. C. Marks. 2006. Plant genes link forests and streams. Ecology 87:255-261.

Lévêque, C. 2003. Ecology: From ecosystem to biosphere. Science Publishers, Enfield, New Hampshire.

Loreau, M. 2002. A new look at the relationship between diversity and stability. Pages 79-91 in M. Loreau, S. Naeem, and P. Inchausti (editors). Biodiversity and ecosystem functioning: Synthesis and perspectives. Oxford University Press, Oxford, United Kingdom.

Marcarelli, A. M., C. V. Baxter, M. M. Mineau, and R. O. Hall. 2011. Quantity and quality: Unifying food web and ecosystem perspectives on the role of resource subsidies in freshwaters. Ecology 92:1215-1225.

Marcarelli, A. M., R. W. Van Kirk, and C. V. Baxter. 2010. Predicting effects of hydrologic alteration and climate change on ecosystem metabolism in a western US river. Ecological Applications 20:2081-2088.

Masseret, E., C. Amblard, and G. Bourdier. 1998. Changes in the structure and metabolic activities of periphytic communities in a stream receiving treated sewage from a waste stabilization pond. Water Research 32:2299-2314.

Matthaei, C. D., J. J. Piggott, and C. R. Townsend. 2010. Multiple stressors in agricultural streams: Interactions among sediment addition, nutrient enrichment and water abstraction. Journal of Applied Ecology 47:639-649.

McGhee, G. R. 2011. Convergent evolution: Limited forms most beautiful. The MIT Press, Cambridge, Massachusetts.

McGill, B. J., B. J. Enquist, E. Weiher, and M. Westoby. 2006. Rebuilding community ecology from functional traits. Trends in Ecology and Evolution 21:178-185.

McKie, B. G., and B. Malmqvist. 2009. Assessing ecosystem functioning in streams affected by forest management: Increased leaf decomposition occurs without changes to the composition of benthic assemblages. Freshwater Biology 54:2086-2100.

McKie, B. G., Z. Petrin, and B. Malmqvist. 2006. Mitigation or disturbance? Effects of liming on macroinvertebrate assemblage structure and leaf-litter decomposition in the humic streams of northern Sweden. Journal of Applied Ecology 43:780-791.

McKie, B. G., M. Schindler, M. O. Gessner, and B. Malmqvist. 2009. Placing biodiversity and ecosystem functioning in context: Environmental perturbations and the effects of species richness in a stream field experiment. Oecologia 160:757770.

Mendoza-Lera, C., A. Larrañaga, J. Pérez, E. Descals, A. Martínez, O. Moya, I. Arostegui, and J. Pozo. 2012. Headwater reservoirs weaken terrestrial-aquatic linkage by slowing leaf-litter processing in downstream regulated reaches. River Research and Applications 28:13-22.

Monroy, S., M. Menéndez, A. Basaguren, J. Pérez, A. Elosegi, and J. Pozo. 2016. Drought and detritivores determine leaf litter decomposition in calcareous streams of the Ebro catchment (Spain). Science of the Total Environment 573:1450-1459.

Moreirinha, C., S. Duarte, C. Pascoal, and F. Cássio. 2011. Effects of cadmium and phenanthrene mixtures on aquatic fungi and microbially mediated leaf litter decomposition. Archives of Environmental Contamination and Toxicology 61:211-219.

Morgan, A. M., T. V. Royer, M. B. David, and L. E. Gentry. 2006. Relationships among nutrients, chlorophyll-a, and dissolved oxygen in agricultural streams in Illinois. Journal of Environmental Quality 35:1110-1117.

Muñoz I., J. C. López-Doval, M. Ricart, M. Villagrasa, R. Brix, A. Geiszinger, A. Ginebreda, H. Guasch, M. J. López de Alda, A. M. Romaní, S. Sabater, and D. Barceló. 2009. Bridging levels of pharmaceuticals in river water with biological community structure in the Llobregat River basin (northeast Spain). Environmental Toxicology and Chemistry 28:2706-2714.

Niyogi, D. K., M. Koren, C. J. Arbuckle, and C. R. Townsend. 2007. Stream communities along a catchment land-use gradient: Subsidy-stress responses to pastoral development. Environmental Management 39:213-225.

Niyogi, D. K., W. M. Lewis Jr., and D. M. McKnight. 2002. Effects of stress from mine drainage on diversity, biomass, and function of primary producers in mountain streams. Ecosystems 5: 554-567.

Niyogi, D. K., K. S. Simon, and C. R. Townsend. 2004. Land use and stream ecosystem functioning: Nutrient uptake in streams that contrast in agricultural development. Archiv für Hydrobiologie 160:471-486.

Odum, E. P., J. T. Finn, and E. Franz. 1979. Perturbation theory and the subsidy-stress gradient. BioScience 29:349-352.

Ormerod, S. J., M. Dobson, A. G. Hildrew, and C. Townsend. 2010. Multiple stressors in freshwater ecosystems. Freshwater Biology 55:1-4.

Palmer, M. A., and C. M. Febria. 2012. The heartbeat of ecosystems. Science 336:1393-1394.

Pascoal, C., and F. Cássio. 2004. Contribution of fungi and bacteria to leaf litter decomposition in a polluted river. Applied and Environmental Microbiology 70:5266-5273.

Pascoal, C., F. Cássio, and P. Gomes. 2001. Leaf breakdown rates: A measure of water quality? International Review of Hydrobiology 86:407-416. 
Pascoal, C., F. Cássio, A. Marcotegui, B. Sanz, and P. Gomes. 2005. Role of fungi, bacteria, and invertebrates in leaf litter breakdown in a polluted river. Journal of the North American Benthological Society 24:784-797.

Patrick, R., B. Crum, and J. Coles. 1969. Temperature and manganese as determining factors in the presence of diatom or blue-green algal floras in streams. Proceedings of the National Academy of Sciences 64:472-478.

Paul, M. J., and J. L. Meyer. 2001. Streams in the urban landscape. Annual Review of Ecology and Systematics 32:333-365.

Peters, K., M. Bundschuh, and R. B. Schäfer. 2013. Review on the effects of toxicants on freshwater ecosystem functions. Environmental Pollution 180:324-329.

Phinney, H. K., and C. D. McIntire. 1965. Effect of temperature on metabolism of periphyton communities in laboratory streams. Limnology and Oceanography 10:341-345.

Piggott, J. J., D. K. Niyogi, C. R. Townsend, and C. D. Matthaei. 2015a. Multiple stressors and stream ecosystem functioning: Climate warming and agricultural stressors interact to affect processing of organic matter. Journal of Applied Ecology 52:1126-1134.

Piggott, J. J., C. R. Townsend, and C. D. Matthaei. 2015b. Reconceptualizing synergism and antagonism among multiple stressors. Ecology and Evolution 5:1538-1547.

Pilière, A. F. H., W. C. E. P. Verberk, M. Gräwe, A. M. Breure, S. D. Dyer, L. Posthuma, D. de Zwart, M. A. J. Huijbregts, and A. M. Schipper. 2016. On the importance of trait interrelationships for understanding environmental responses of stream macroinvertebrates. Freshwater Biology 61:181-194.

Piscart, C., R. Genoel, S. Dolédec, E. Chauvet, and P. Marmonier. 2009. Effects of intense agricultural practices on heterotrophic processes in streams. Environmental Pollution 157:1011-1018.

Poff, N. L., and J. D. Allan. 1995. Functional organization of stream fish assemblages in relation to hydrological variability. Ecology 76:606-627.

Poff, N. L., M. I. Pyne, B. P. Bledsoe, C. C. Cuhaciyan, and D. M. Carlisle. 2010. Developing linkages between species traits and multiscaled environmental variation to explore vulnerability of stream benthic communities to climate change. Journal of the North American Benthological Society 29:1441-1458.

Poff, N. L., N. J. Voelz, J. V. Ward, and R. E. Lee. 1990. Algal colonization under four experimentally-controlled current regimes in a high mountain stream. Journal of the North American Benthological Society 9:303-318.

Puche, E., F. Jordán, M. A. Rodrigo, and C. Rojo. 2020. Nontrophic key players in aquatic ecosystems: A mesocosm experiment. Oikos early view. (Available from: https://doi.org/10 .1111/oik.07476)

Raffard, A., A. Lecerf, J. Cote, M. Buoro, R. Lassus, and J. Cucherousset. 2017. The functional syndrome: Linking individual trait variability to ecosystem functioning. Proceedings of the Royal Society B: Biological Sciences 284:20171893.

Rasmussen, J. J., A. Baattrup-Pedersen, T. Riis, and N. Friberg. 2011. Stream ecosystem properties and processes along a temperature gradient. Aquatic Ecology 45:231-242.

Rasmussen, J. J., P. Wiberg-Larsen, A. Baattrup-Pedersen, R. J. Monberg, and B. Kronvang. 2012. Impacts of pesticides and natural stressors on leaf litter decomposition in agricultural streams. Science of the Total Environment 416:148-155.

Riipinen, M. P., J. Davy-Bowker, and M. Dobson. 2009. Comparison of structural and functional stream assessment methods to detect changes in riparian vegetation and water $\mathrm{pH}$. Freshwater Biology 54:2127-2138.

Riis, T., and B. J. F. Biggs, 2003. Hydrologic and hydraulic control of macrophyte establishment and performance in streams. Limnology and Oceanography 48:1488-1497.

Roberts, B. J., P. J. Mulholland, and W. R. Hill. 2007. Multiple scales of temporal variability in ecosystem metabolism rates: Results from 2 years of continuous monitoring in a forested headwater stream. Ecosystems 10:588-606.

Robinson, C. T., M. O. Gessner, and J. V. Ward. 1998. Leaf breakdown and associated macroinvertebrates in alpine glacial streams. Freshwater Biology 40:215-228.

Rosenberg, D. M., and V. H. Resh (editors). 1993. Freshwater biomonitoring and benthic macroinvertebrates. Chapman and Hall, New York, New York.

Rosenzweig, M. L. 1995. Species diversity in space and time. Cambridge University Press, New York, New York.

Rubach, M. N., R. Ashauer, D. B. Buchwalter, H. J. De Lange, M. Hamer, T. G. Preuss, K. Töpke, and S. J. Maund. 2011. Framework for traits-based assessment in ecotoxicology. Integrated Environmental Assessment and Management 7:172-186.

Rubach, M. N., D. J. Baird, and P. J. Van den Brink. 2010. A new method for ranking mode-specific sensitivity of freshwater arthropods to insecticides and its relationship to biological traits. Environmental Toxicology and Chemistry 29:476-487.

Ryan, P. A. 1991. Environmental effects of sediment on New Zealand streams: A review. New Zealand Journal of Marine and Freshwater Research 25:207-221.

Saito, V. S., M. V. Cianciaruso, T. Siqueira, A. A. FonsecaGessner, and S. Pavoine. 2016. Phylogenies and traits provide distinct insights about the historical and contemporary assembly of aquatic insect communities. Ecology and Evolution 6:2925-2937.

Saito, V. S., T. Siqueira, and A. A. Fonseca-Gessner. 2015. Should phylogenetic and functional diversity metrics compose macroinvertebrate multimetric indices for stream biomonitoring? Hydrobiologia 745:167-179.

Sariyildiz, T. and J. M. Anderson, J. M. 2003. Decomposition of sun and shade leaves from threedeciduous tree species, as affected by their chemical composition. Biology and Fertility of Soils 37:137-146.

Savoy, P., A. P. Appling, J. B. Heffernan, E. G. Stets, J. S. Read, J. W. Harvey, and E. S. Bernhardt. 2019. Metabolic rhythms in flowing waters: An approach for classifying river productivity regimes. Limnology and Oceanography 64:1835-1851.

Schäfer, R. B., T. Caquet, K. Siimes, R. Mueller, L. Lagadic, and M. Liess. 2007. Effects of pesticides on community structure and ecosystem functions in agricultural streams of three biogeographical regions in Europe. Science of the Total Environment 382:272-285.

Schäfer, R. B., B. Kühn, E. Malaj, A. König, and R. Gergs. 2016. Contribution of organic toxicants to multiple stress in river ecosystems. Freshwater Biology 61:2116-2128.

Schäfer, R. B., P. C. von der Ohe, J. Rasmussen, B. J. Kefford, M. A. Beketov, R. Schulz, and M. Liess. 2012b. Thresholds for the effects of pesticides on invertebrate communities and leaf breakdown in stream ecosystems. Environmental Science \& Technology 46:5134-5142.

Schlief, J., and M. Mutz. 2009. Effect of sudden flow reduction on the decomposition of alder leaves (Alnus glutinosa [L.] Gaertn.) 
in a temperate lowland stream: A mesocosm study. Hydrobiologia 624:205-217.

Schofield, K. A., C. M. Pringle, and J. L. Meyer. 2004. Effects of increased bedload on algal- and detrital-based stream food webs: Experimental manipulation of sediment and macroconsumers. Limnology and Oceanography 49:900-909.

Seibold, S., M. W. Cadotte, J. S. MacIvor, S. Thorn, and J. Müller. 2018. The necessity of multitrophic approaches in community ecology. Trends in Ecology and Evolution 33:754-764.

Sims, A., Y. Zhang, S. Gajaraj, P. B. Brown, and Z. Hu. 2013. Toward the development of microbial indicators for wetland assessment. Water Research 47:1711-1725.

Smeti, E., D. von Schiller, I. Karaouzas, S. Laschou, L. Vardakas, S. Sabater, E. Tornés, L. S. Monllor-Alcaraz, N. Guillem-Argiles, E. Martinez, D. Barceló, M. López de Alda, E. Kalogianni, A. Elosegi, and N. Skoulikidis. 2019. Multiple stressor effects on biodiversity and ecosystem functioning in a Mediterranean temporary river. Science of the Total Environment 647:1179-1187.

Smucker, N. J., S. A. Drerup, and M. L. Vis. 2014. Roles of benthic algae in the structure, function, and assessment of stream ecosystems affected by acid mine drainage. Journal of Phycology 50:425-436.

Southwood, T. R. E. 1977. Habitat, the templet for ecological strategies? Presidential address to the British Ecological Society. Journal of Animal Ecology 46:337-365.

Sponseller, R. A., and E. F. Benfield. 2001. Influences of land use on leaf breakdown in southern Appalachian headwater streams: A multiple-scale analysis. Journal of the North American Benthological Society 20:44-59.

Statzner, B., and L. A. Bêche. 2010. Can biological invertebrate traits resolve effects of multiple stressors on running water ecosystems? Freshwater Biology 55:80-119.

Steinman, A. D., and C. D. McIntire. 1987. Effects of irradiance on the community structure and biomass of algal assemblages in laboratory streams. Canadian Journal of Fisheries and Aquatic Sciences 44:1640-1648.

Stevenson, R. J. 1990. Benthic algal community dynamics in a stream during and after a spate. Journal of the North American Benthological Society 9:277-288.

Suberkropp, K., and E. Chauvet. 1995. Regulation of leaf breakdown by fungi in streams: Influences of water chemistry. Ecology 76:1433-1445.

Tank, J. L., E. J. Rosi-Marshall, N. A. Griffiths, S. A. Entrekin, and M. L. Stephen. 2010. A review of allochthonous organic matter dynamics and metabolism in streams. Journal of the North American Benthological Society 29:118-146.

Thompson, R. M., and C. R. Townsend. 2005. Energy availability, spatial heterogeneity, and ecosystem size predict food-web structure in streams. Oikos 108:137-148.

Tilman, D. 2001. Functional diversity. Pages $109-120$ in S. A. Levin (editor). Encyclopedia of biodiversity, volume 3. Academic Press, San Diego, California.

Tiunov, A. V., and S., Scheu. 2005. Facilitative interactions rather than resource partitioning drive diversity-functioning relationships in laboratory fungal communities. Ecology Letters 8:618-625.

Townsend, C. R., and R. H. Riley. 1999. Assessment of river health: Accounting for perturbation pathways in physical and ecological space. Freshwater Biology 41:393-405.

Townsend, C. R., R. M. Thompson, A. R. McIntosh, C. Kilroy, E. Edwards, and M. R. Scarsbrook. 1998. Disturbance, resource supply and food-web architecture in streams. Ecology Letters 1:200-209.

Truchy, A., E. Göthe, D. G. Angeler, F. Ecke, R. A. Sponseller, M. Bundschuh, R. K. Johnson, and B. G. McKie. 2019. Partitioning spatial, environmental, and community drivers of ecosystem functioning. Landscape Ecology 34:2371-2384.

Udy, J. W., C. S. Fellows, M. E. Bartkow, S. E. Bunn, J. E. Clapcott, and B. D. Harch. 2006. Measures of nutrient processes as indicators of stream ecosystem health. Hydrobiologia 572:89-102.

Uehlinger, U. 2000. Resistance and resilience of ecosystem metabolism in a flood-prone river system. Freshwater Biology 45:319-332.

Uehlinger, U. 2006. Annual cycle and inter-annual variability of gross primary production and ecosystem respiration in a floodprone river during a 15-year period. Freshwater Biology 51:938-950.

Uehlinger, U., B. Kawecka, and C. T. Robinson. 2003. Effects of experimental floods on periphyton and stream metabolism below a high dam in the Swiss Alps (River Spöl). Aquatic Sciences 65:199-209.

Uehlinger, U., and M. W. Naegeli. 1998. Ecosystem metabolism, disturbance, and stability in a prealpine gravel bed river. Journal of the North American Benthological Society 17:165-178.

USEPA (United States Environmental Protection Agency). 2002. Summary of biological assessment programs and biocriteria development for states, tribes, territories, and interstate commissions: Streams and wadeable rivers. EPA-822-R-02-048. Office of Environmental Information and Office of Water, United States Environmental Protection Agency, Washington, DC. (Available from: https://nepis.epa.gov/Exe/ZyPURL.cgi?Dockey $=20003$ JHM.txt)

Val, J., D. Chinarro, M. R. Pino, and E. Navarro. 2016. Global change impacts on river ecosystems: A high-resolution watershed study of Ebro river metabolism. Science of the Total Environment 569:774-783.

Vermaat, J. E., and M. J. M. Hootsmans. 1994. Periphyton dynamics in a temperature-light gradient. Pages 193-212 in W. van Vierssen, M. Hootsmans, and J. Vermaat (editors). Lake Veluwe, a macrophyte-dominated system under eutrophication stress. Springer, Dordrecht, The Netherlands.

Vilches, C., and A. Giorgi. 2010. Metabolism in a macrophyterich stream exposed to flooding. Hydrobiologia 654:57-65.

Vinebrooke, D., R. L. Cottingham, K. Norberg, M. Scheffer, J. I. Dodson, S. C. Maberly, and U. Sommer. 2004. Impacts of multiple stressors on biodiversity and ecosystem functioning: The role of species co-tolerance. Oikos 104:451-457.

von Schiller, D., V. Acuña, I. Aristi, M. Arroita, A. Basaguren, A. Bellin, L. Boyero, A. Butturini, A. Ginebred, E. Kalogianni, A. Larrañaga, B. Majone, A. Martínez, S. Monroy, I. Muñoz, M. Paunović, O. Pereda, M. Petrovic, J. Pozo, S. RodríguezMozaz, D. Rivas, S. Sabater, F. Sabater, N. Skoulikidis, L. Solagaistua, L. Vardakas, and A. Elosegia. 2017. River ecosystem processes: A synthesis of approaches, criteria of use and sensitivity to environmental stressors. Science of the Total Environment 596-597:465-480.

Wagenhoff, A., C. R. Townsend, N. Phillips, and C. D. Matthaei. 2011. Subsidy-stress and multiple-stressor effects along gradients of deposited fine sediment and dissolved nutrients in a regional set of streams and rivers. Freshwater Biology 56:1916-1936. 
Wallace, J. B., J. W. Grubaugh, and M. R. Whiles. 1996. Biotic indices and stream ecosystem processes: Results from an experimental study. Ecological Applications 6:140-151.

Walsh, C. J., A. H. Roy, J. W. Feminella, P. D. Cottingham, P. M. Groffman, and R. P. Morgan. 2005. The urban stream syndrome: Current knowledge and the search for a cure. Journal of the North American Benthological Society 24:706-723.

Webb, C. O., D. D. Ackerly, M. A. McPeek, and M. J. Donoghue. 2002. Phylogenies and community ecology. Annual Review of Ecology and Systematics 33:475-505.

Webster, J. R., and E. F. Benfield. 1986. Vascular plant breakdown in freshwater ecosystems. Annual Review of Ecology and Systematics 17:567-594.

Wellnitz, T., and R. B. Rader. 2003. Mechanisms influencing community composition and succession in mountain stream periphyton: Interactions between scouring history, grazing, and irradiance. Journal of the North American Benthological Society 22:528-541.

Wiederholm, T. 1980. Use of benthos in lake monitoring. Journal (Water Pollution Control Federation) 52:537-547.

Wilkes, M. A., M. Mckenzie, J. F. Murphy, and R. P. Chadd. 2017. Assessing the mechanistic basis for fine sediment biomonitoring: Inconsistencies among the literature, traits and indices. River Research and Applications 33:1618-1629.

Winemiller, K. O. 1992. Life history strategies and the effectiveness of sexual selection. Oikos 62:318-327.

Winemiller, K. O., D. B. Fitzgerald, L. M. Bower and E. R. Pianka. 2015. Functional traits, convergentevolution, and periodic tables of niches. Ecology letters 18:737-751.

Woodcock, T. S., and A. D. Huryn. 2004. Effects of roadway crossings on leaf litter processing and invertebrate assem- blages in small streams. Environmental Monitoring and Assessment 93:229-250.

Woodcock, T. S., and A. D. Huryn. 2005. Leaf litter processing and invertebrate assemblages along a pollution gradient in a Maine (USA) headwater stream. Environmental Pollution 134: 363-375.

Woodward, G., M. O. Gessner, P. S. Giller, V. Gulis, S. Hladyz, A. Lecerf, B. Malmqvist, B. G. McKie, S. D. Tiegs, H. Cariss, M. Dobson, A. Elosegi, V. Ferreira, M. A. S. Graça, T. Fleituch, J. O. Lacoursière, M. Nistorescu, J. Pozo, G. Risnoveanu, M. Schindler, A. Vadineanu, L. B. M. Vought, and E. Chauvet. 2012. Continental-scale effects of nutrient pollution on stream ecosystem functioning. Science 336:1438-1440.

Woodward, G., D. M. Perkins, and L. E. Brown. 2010. Climate change and freshwater ecosystems: Impacts across multiple levels of organization. Philosophical Transactions of the Royal Society B: Biological Sciences 365:2093-2106.

Wright, J. P., and C. G. Jones. 2006. The concept of organisms as ecosystem engineers ten years on: Progress, limitations, and challenges. BioScience 56:203-209.

Young, R. G., and K. J. Collier. 2009. Contrasting responses to catchment modification among a range of functional and structural indicators of river ecosystem health. Freshwater Biology 54:2155-2170.

Young, R. G., and A. D. Huryn. 1999. Effects of land use on stream metabolism and organic matter turnover. Ecological Applications 9:1359-1376.

Young, R. G., C. D. Matthaei, and C. R. Townsend. 2008. Organic matter breakdown and ecosystem metabolism: Functional indicators for assessing river ecosystem health. Journal of the North American Benthological Society 27:605-625. 